\title{
Textography as a needs analysis and research tool for English for Academic Purposes and learning development practitioners
}

\section{Jennifer Sizer}

University of Portsmouth, UK

\section{Abstract}

The purpose of this paper to introduce textography as a useful method for English for academic purposes (EAP) and learning development (LD) practitioners to fill gaps in subject-specific knowledge and understanding. Textography is a research method that may be new to many practitioners. Textography combines textual analysis, usually associated with EAP, and ethnographic methods, often associated with LD, to investigate contexts, texts and practices. EAP and LD practitioners can use textography with accessible texts as initial needs analysis before reviewing literature or as a more in-depth, long-term research tool.

Keywords: practitioner research; textography; ethnography; textual analysis; practice; context.

\section{Introduction}

It is widely accepted that academic literacy practices vary between, and even within, contexts and disciplines (Russell et al., 2005; Lillis and Tuck, 2016). Therefore, students require multiple academic literacies or understanding of associated practice(s), cultural norms, values, genres, and expectations of their discipline and context (Becher and Trowler, 2001; Neumann, 2001; Basturkmen, 2003; Archer, 2006; Jacobs, 2007; Trowler et al., 2014; Flowerdew and Costley, 2017). Street et al., (2015) strongly suggest academic literacies, and practitioners working within academic literacies, should be working towards making these multiple literacies visible. 
However, developing a greater understanding of the varying, often implicit, demands across diverse contexts/disciplines can be challenging for practitioners working within English for Academic Purposes (EAP) /Learning Development (LD). Firstly, available research may not be relevant for the students' subject of study. The research may be too generic and feature an English for General Academic Purposes approach (EGAP) (Blue, 1988). This EGAP approach is also reflective of the study skills model that assumes knowledge of academic writing can be transferred unproblematically between contexts (Lea and Street, 2006). Generic research featuring these approaches includes Coxhead's (2000, p. 213) original 'academic word list' that claimed to cover 'all' academic subjects. Coxhead and others have since advocated more specificity in academic writing research (Hyland, 2002b, 2002a, 2017; Coxhead, 2011).

Despite these calls, academic writing research has some underrepresented subject areas. Academic disciplines such as business have higher numbers of students (nearly 350,000 enrolments in the UK in 2017/18 according to HESA, 2019), so texts are more abundant and may feature more frequently in academic writing studies. In contrast, some academic disciplines, e.g. creative arts and design, have smaller numbers of students (around half the number of business enrolments in 2017/18 according to HESA, 2019). This may result in fewer researchable student texts, particularly in subject areas with fewer students and/or higher frequency of student texts which can be difficult to incorporate into corpus research e.g. multimodal texts. This may explain the absence of arts and design texts from many corpora including British Academic Written English (BAWE) corpus (Coventry University, 2019) and corpus research including Coxhead's academic word list.

Practitioners may have difficulty in locating relevant research, particularly for subject areas with fewer students, texts/research studies.

Alternatively, practitioners may discover research that appears superficially relevant for the subject but may find contextual factors have a significant impact on practice(s) and texts. Academic literacies research often features ethnography, which can provide highly contextualised academic writing studies (Lillis, 2008; Street et al., 2015). This can be a strength if working in a similar context, but contextual factors can be difficult to identify, particularly when working with a less familiar subject area. Texts produced by students may superficially appear to be from one subject area but may also be influenced by the 
context: linguistic context, university structures/management, academic specialisms, and interdisciplinarity of some courses. Multilingual, plurilingual, or bilingual academic contexts may have significant impacts on textual practices and production even within similar disciplines/subjects (see Curry's work, e.g. Lillis and Curry, 2006). In terms of structure, for historical and logistical reasons courses may be aligned in several divergent university structures. For example, some contexts may place a subject such as architecture within creative faculties and subsequent texts may be more art and design based. Other universities may place architecture within science faculties and subsequent texts may be more engineering based. Academics working within specific disciplines or subject areas may also have diverse specialisms resulting in diverse identities and texts, for example, see Archer's (2006) work on engineering identities and posters. Conversely, academics may share a narrow field of specialism within the subject area which may further impact texts and practices.

One strategy to ensure research relevance is for EAP and LD practitioners to conduct subject-specific research within their own contexts. However, this can seem a daunting challenge, particularly in terms of financial and time commitments, for many colleagues for whom research is not an explicit/paid element of their job role (see commentary on role of research for LD and EAP practitioners from Johnson, 2018; Sizer, 2019a). I suggest one solution for practitioners is performing a subject-specific and contextual needs analysis using textography. Needs analysis is defined here as establishing the contextual situation through textual analysis of the target situation (Dudley-Evans and St John, 1998). Textography as an initial needs analysis tool provides practitioners with opportunities to explore lesser-known subject areas through accessible texts within their own contexts. Textography as a research method provides an in-depth highly contextualised study of texts and practices within a specific subject.

\section{Textography}

Textography brings together research methods often utilised by both EAP and LD practitioners. Textography blends linguistics research involving textual analysis with academic literacies research featuring a 'strong ethnographic orientation' (Street et al., 2015, p. 395). Ergo, textual analysis with ethnography becomes textography. Lillis and 
Scott (2007) suggest academic literacies research can involve investigating the 'nature of academic writing in different sites' (p. 9). Similarly, the aim of textography is to research academic writing within a specific context.

\section{Textography history}

The first recorded use of the term textography was in 1998 by John Swales. Swales is well-known for his text-based research within EAP (Swales, 1990, 2000, 2003). However, Swales' site-based textographic study brought textual analysis and ethnography together to investigate three academic communities (including his own community) within one university building. Swales (1990, p. 1) described his textography as 'something more than a disembodied textual or discoursal analysis, but something less than a full ethnographic account'. Paltridge (2008, p. 11) describes a textography's aim as examining the 'contextualization' and the 'situatedness' of written texts and textual practices and get an 'inside view of the worlds in which the texts are written' (Paltridge et al., 2012, p. 992). In the editor's introduction of Swales' 'Other Floors, Other Voices: a Textography of a Small University Building' Bazerman describes Swales wandering the context collecting texts and discovering distinct textual practices, 'cultures and ways of life' (Bazerman, 1998, p. ix-x). Swales (1998) collected a variety of texts e.g. memos, CVs, journal articles, minutes, signs, and notes in order to explore the culture, community and context.

Firstly, Swales (1998) used archival research to explore the history of the university building and three communities within the building: the Herbarium, the Computing Resource Site, and the English Language Institute. This archival research was combined with photographs of the context and its texts to provide a 'pictorial sense of the building' (Paltridge, 2008, p. 11). The use of photography is well established in ethnographic research (see work by Schwartz, 1989; Pink, 2012, 2013; Heng, 2017;) and in academic literacies research (Ingle and Yakovchuk, 2015). Swales (1998, p.26) also collected texts representing 'routine business' of the three communities, such as memos, signs, and other correspondence, as well as longer written texts more closely associated with academic communities such as; journal articles, monographs, and floras from the Herbarium. Alongside collecting and photographing texts, Swales also observed the communities and made field notes of observations (Swales, 1998). Swales then reassembled the texts to 
create textual histories (Swales, 1998). These textual histories provided a narrative for subsequent interviews but were not necessarily examples of narrative enquiry which often involve participants writing their own personal narratives, (see Hale at al., 2007). Finally, Swales then interviewed the participants. Swales (1998) found differing voices, texts, and textual practices in the three contexts/cultures. Subsequently, Swales defined two of the contexts as distinct 'Place Discourse Communities': a group of people who work together and use a range of genres that have evolved during the existence of their community (Paltridge, 2008).

Swales' textography represented a step away from more traditional textual analysis and often purely etic approach from an outsider researcher perspective external to the community being researched (Lillis, 2008) which is often associated with linguistics and EAP research. Swales' textography explores situated writing practices and texts in the context using a more emic approach from an insider writer perspective (Lillis, 2008) using ethnographic methods within his own academic community. In addition, Swales included other academic communities providing opportunities for a more 'emic/etic approach' exploring relationships between insiders' and outsiders' views (Street, 2012, p. 41) and allowing for comparisons between communities.

\section{Textography benefits}

One of the major benefits for practitioners using textography as needs analysis is contextual relevance. This focus on context is often achieved through photography and observation of texts and practice in-situ during site-based studies. Lillis (2008, p. 354) claims there is 'growing recognition for the need to focus on the context of writing'. Lillis and Tuck (2016) also emphasise this need 'for ethnographic methodologies which facilitate analysis of texts as part of contexts' (p. 39). In this paper, I suggest textography as a research method that answers these calls (Lillis and Scott, 2007; Lillis, 2008; Lillis and Tuck, 2016). Textography as a research method combines textual analysis of contextualised-writing and ethnography (Swales, 1998). This method can be helpful for both learning developers and EAP practitioners, not only to investigate the context, but also to place equal emphasis on both texts and practices of specific communities at university (see equilateral triangles (figure 1 and figure 2) below). 


\section{Figure 1}

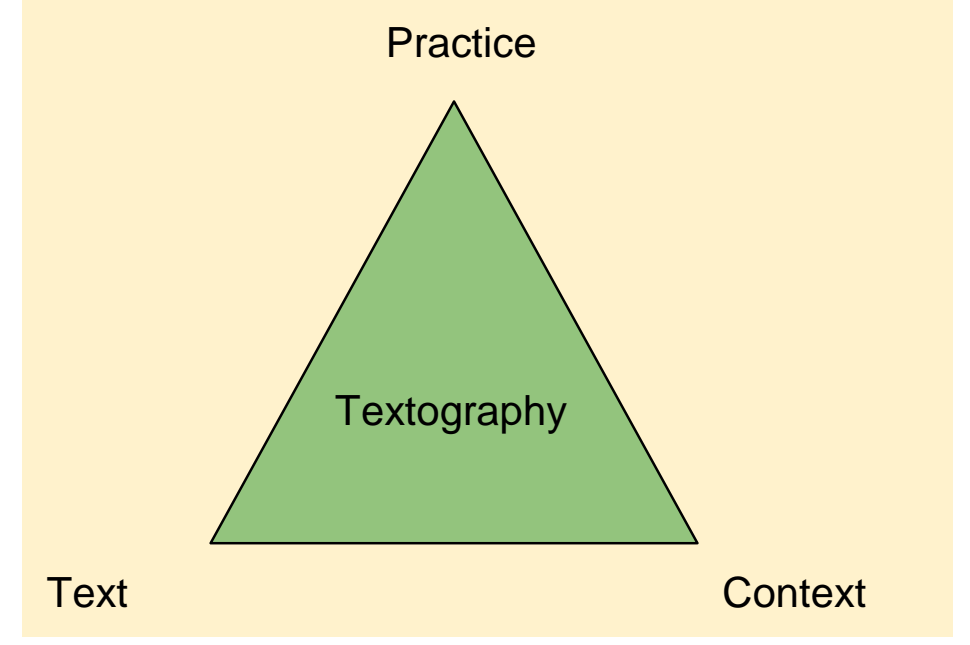

\section{Figure 2}

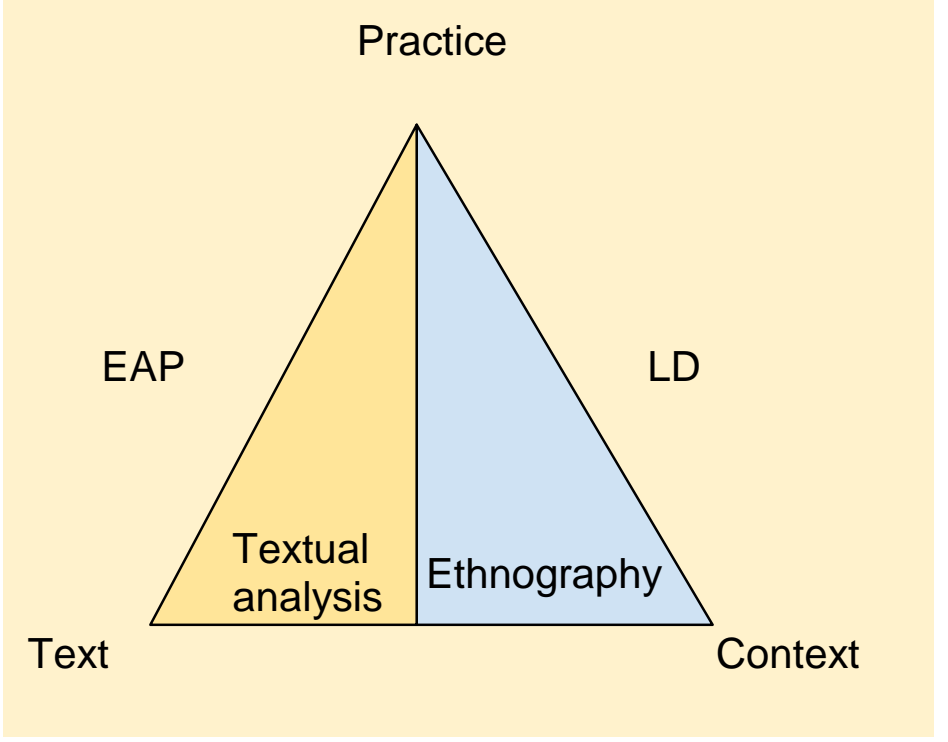

Attempts to research a community's context, texts and practices together via textography also counteracts some of the criticisms levelled at research emphasising just one of these elements. The focus of much EAP research is on texts (Lillis and Tuck, 2016) through corpus linguistics, systemic functional linguistics, genre analysis, and discourse analysis (Ding and Bruce, 2017). Expert analysis of texts alone uses a more 'etic' outsider perspective and can often ignore the text's audience and authors and resulting practices (Lillis and Tuck, 2016). In contrast to text-focused EAP research, academic literacies 
research focusses on the 'interpreters' of the text (Ding and Bruce, 2017, p. 79) or 'producers and meaning makers' (Lillis and Tuck, 2016, p. 41). Academic literacies research avoids a myopic focus on texts and instead claims a 'wider-lens' view which challenges textual bias by shifting focus away from texts, towards practices ( Lillis and Scott, 2007; Ding and Bruce, 2017, p.78). For learning developers, informed by academic literacies, the principal research methodology for investigating practice is often ethnography (Lillis and Scott, 2007). However, Lillis and Scott (2007) warn that ethnographies' focus on practice at the expense of texts could result in detailed textual analysis disappearing from academic literacies research. Lea and Street (1998, p. 160) emphasise the 'importance of understanding both texts and practices' and Lillis and Scott (2007) call for research 'to bring the text back into the frame' (p. 22). Lillis and Tuck (2016) also highlight calls from Lillis (2008) and Hyland (2002a) for research methods that enable more holistic accounts including both texts and practices. Pérez-Penup (2019) goes further and suggests using textography can strengthen ethnographic data with textual analysis.

\section{Textography uses}

Since Swales' original work, textography has been used to investigate a broad range of contexts, practices, and texts. Textography as a highly contextualised study of situated writing practices can help practitioners identify relevant research and resources/gaps in literature within a specific, potentially less familiar, subject area. Textography has been used to illuminate textual practices of academics, students, and practitioners within specific academic contexts.

\section{Less charted territories}

Swales' original textography provided an in-depth account of three communities with different disciplines within a shared context. One of the communities, the Herbarium, had very little literature on texts and textual practices. Swales was able to use discourse and genre analysis to identify key features of unique specialised texts produced by the Herbarium such as floras and monographs. Swales' time spent in the Herbarium also allowed him to go beyond pure textual analysis and explore the context in more detail and observe textual practices in action. Swales has since published a follow-up study of 
Herbarium texts and claims such texts 'remain little known to those who study the more general discourses of the academic and research world' (Mccarty and Swales, 2017, p. 561). Following Swales, a number of research studies featuring textography have also focussed on subject areas with less associated research such as art history (Seloni, 2014) and librarianship (Pérez-Penup, 2019). Other textographic research has featured subjects with less associated research and also unique or unusual texts for example visual and performing arts, including subject-specific texts such as practice-based doctoral theses (Paltridge et al., 2012; Ravelli et al., 2013; Starfield at al., 2014), art, and design, including subject-specific texts such as exegesis (Paltridge, 2004, 2008). Swales' and other previously mentioned textographers' subsequent interviews with participants about their textual histories and features of texts encouraged implicit textual practices to become visible and shared with a wider audience, including EAP and LD practitioners, via published research. In order to make textual and contextual practices of a specific discipline more explicit, EAP and LD practitioners can use textography as an initial needs analysis tool. The results of this needs analysis can then be used to find relevant literature or continue research to fill a gap in the literature, as in textographies previously mentioned.

In addition, needs analysis, via textography, can be small-scale, short-term and even unobtrusive research by focussing on accessible contexts, texts, and practices. Unobtrusive textographic research can involve collecting accessible texts from the context using photography and ethnographic observations (Sizer, 2019b). EAP and LD practitioners can collect a range of accessible texts to create a detailed picture of a discipline's context and likely textual practices:

- Accessible physical texts within the discipline's context (building): signs, leaflets, handouts.

- Accessible institutional texts about discipline: unit/course descriptors, assessment guidelines, reading lists, course/subject marketing publications, e.g. leaflets, website, social media.

- Accessible electronic texts via discipline's virtual learning environment: lecture slides, discussion boards, suggested reading, external examiner/inspection reports, course/unit feedback. 
- Accessible electronic texts authored by discipline's academics: academic biographies (often on website and research portal) journal articles, other articles e.g. The Conversation, PhD theses via the British Library's 'e-theses online service' (EThOS), academics' social media/blogs.

- Accessible electronic texts authored by discipline's students: example dissertations within the discipline (often held by university library and other external examples may be accessible via EthoS), examples of student work within the discipline (often shared with external examiners/students using virtual learning environment/HEl's dissertation repository and other external examples may be accessible via BAWE and other corpora).

This focus on accessibility can also negate the need for permission from texts' authors/audiences, not only minimising timeframe but also reducing the need for ethical approval from universities. Freedom to research a discipline's context, texts, and practices without involving participants can be a liberating and fast way to extend knowledge, particularly for colleagues discouraged from participating in research. The accessibility of electronic texts may also allow for a virtual textography investigating contexts such as a distance learning course as featured in Souza's (2012) textography. Virtual textography may also be helpful for practitioners interested in less accessible academic communities or contexts such as university courses involving placements such as medical courses. Virtual textography can also be used as a needs analysis before gaining access to a less accessible context, such as in another country or outside academia such as schools, colleges, or training centres, e.g. English for military or aviation industry. The information gathered from this needs analysis can then be compared to other available literature on less-accessible contexts.

\section{Academic textography}

Most published textographies feature subject-specific university contexts with some focus on texts for and by academics within the discipline. Swales' (1998) textography collected a wide variety of texts including those authored by academics such as journal articles. Swales combined genre analysis of academic texts with ethnographic interviews and 
found the contexts had textual, temporal, and spatial differences. Pérez-Penup's (2019) textography took a similar approach to Swales. Through analysis of texts and interviews, Pérez-Penup (2019) found a great deal of intertextuality, or relationships, between texts. The textography had a similar focus to Lillis and Curry's (2006) academic literaciesinformed work on multilingual scholars. Swales and Pérez-Penup's textographic research showcases successful examples of EAP and LD practitioners working with academics in different disciplines to make textual practices within the context visible. Academics as participants in research is one strategy EAP and LD practitioners can use in order to move towards collaboration with disciplines and subject experts (Dudley-Evans and St John, 1998) and move away from handmaiden or waiter roles merely serving or cooperating with the needs of the individual disciplines and wider university (Raimes, 1991; Dudley-Evans and St John, 1998; Hyland, 2006).

Identifying and recruiting academics as participants in textography research can be challenging, not only due to the perceived role of EAP/LD practitioners, but also due to disciplinary variations such as research methods. Subject/discipline experts are not language nor literacies experts and may find research methods and associated jargon from other disciplines, particularly some linguistic terminology, difficult to navigate. Textography's combination of a variety of methods: textual analysis (often featuring more quantitative data, e.g. corpus linguistics) alongside ethnography (photographing texts in context, observing textual practices, and interviewing participants) may make the research more relevant and participation more appealing for some subject/discipline experts. Textography has the versatility to incorporate a wide range of textual analysis methods and ethnographic methods to fit the context and subject of study. This could include, for example, focus groups in business contexts to discuss and reflect on textual practices and textual products, or could incorporate multimodal text analysis in contexts where visual literacy is important such as creative arts, journalism, engineering, and medicine. (Archer, 2006; Thompson, 2019). Including research methods familiar to the participant, researcher and area researched may even enhance understanding and engagement with academic literacies research.

The fusion of methods associated with EAP (textual analysis) and methods associated with LD (ethnography) also provides further opportunities for collaboration with other 
colleagues. Future collaborative textographic projects could include working with other LD and EAP practitioners and other colleagues at the same institution to investigate the same subject area. Alternatively, other future research projects could involve colleagues coming together from similar contexts at different universities comparing texts and practices from the same subject/discipline area, perhaps via crowd-sourced corpora.

\section{Student textography}

The academic textographies from Swales and Pérez-Penup provided an in-depth contextual investigation of the academic texts from a specific subject area. However, much of the focus was on journal articles and other texts by academics with a notable absence of texts from students (Swales, 1998). This would seem to perpetuate the deficit model, in which the academics are experts and students are novices, and journal articles are writing models for students to emulate ( Lillis and Scott, 2007; Jacobs, 2015; Lillis et al., 2015; Lillis and Tuck, 2016;). Other textographies focussed more on texts for and by students rather than academics within the context. Most of these textographies included texts authored by students. Lontoc's (2014) textography included draft and final submissions of student essays as well as classroom observations and focus groups with teachers in a high school in the Philippines. Lontoc's research, like Pérez-Penup (2019), used discourse analysis to investigate identity but instead focused on students. Paltridge's (2006) textography also included textual analysis of student essays and ethnographic data from teachers to highlight textual practice. Paltridge's study also included multimodal textbooks and interviews with examiners about expectations and requirements for exams. Alongside colleagues in Australia, Paltridge also conducted a further textography including students' practice-based doctoral theses (Paltridge et al., 2012; Ravelli et al., 2013). They used textual analysis and ethnographic interviews to discuss the macrostructure of multimodal theses including a visual or performative component. Seloni's (2014) textography featured multimodal texts from art history to investigate macrostructure and included drafts and other texts from the same authors promoting opportunities to explore intertextuality and textual practices.

Future student textographies could also foster collaboration and working with rather than working for students. Students participating in textography can also collect texts within 
contexts through photo-ethnography (Mannion and Ivanič, 2007) collect texts through a 'do-it-yourself-corpus' (Charles, 2012) perform their own auto-ethnographic observations reflecting on their subject's textual practices. Textographies could also incorporate more creative ethnographic research methods for students studying creative subjects, such as participant self-portraits (Gourlay, 2009), and annotated maps/floor plans of context (Mannion and Ivanič, 2007).

\section{Practitioner textography}

In addition to in-depth contextual research on another discipline, textography can also be used by practitioners to investigate and reflect on their own discipline and associated context, practices and texts. To some extent, Swales (1998) used an auto-textographic approach by analysing his own texts and those of his colleagues working within the same context: the English Language Institute. Souza's (2012) auto-textography collected and reflected on online multimodal texts she shared with a virtual discourse community both, as a distance learner, and as a teacher. Januin and Stephen's (2015) textography reflected on own practices and student texts during an EAP course in Malaysia. Alafnan's (2016) textography also used an auto-textography approach but emphasised one institution-wide community, rather than disciplinary community, connected through shared textual practices and business communication. This auto-textography collected examples of 'routine business' (Swales, 1998) which Alafnan analysed for shared genres and combined with his own reflections on texts and practices. Other textographies have focussed on texts produced by the context and community in the form of textbooks. Both textbook textographies used genre analysis of multimodal textbooks alongside ethnographic interviews with teachers and suggested ways in which textbooks could be improved for students and teachers at Indonesian and Chinese universities (Wahyudi, 2014; Zhu et al., 2016). Practitioner textographic research can be a helpful reflection tool in order to investigate own practices and texts within own context and discipline. Practitioner textographies also provide opportunities to promote transformative practice through change in own and others' practice and texts (Jacobs, 2015), rather than a more normative approach of reporting the textual practices of others in another context. 


\section{Conclusion}

Textography can be used by EAP/LD practitioners to produce highly contextualised studies of a discipline's texts and practices. This type of study provides practitioners with subject-specific knowledge that is both contextually relevant and holistic through the inclusion of both texts and practices. Practitioners can use textography as an initial method for needs analysis in order to explore contexts and collect texts, either accessible texts or texts requiring permission, and practices of an area which practitioners are less familiar with. Textographic results can make a specific subject's textual practices more visible and indicate relevant literature and materials to support students studying within the subject area and context. Results may also indicate a literature gap to be filled through further research with and within the community. Textographies can be very versatile in terms of text collection: accessible texts for unobtrusive research, electronic texts for virtual research, and multimodal texts for research with subjects requiring visual literacy. Textographies can also investigate subject areas from varying perspectives through the inclusion of texts for and by academics and texts for and by students. Finally, textography can be used by practitioners themselves to reflect on own context, texts, and practices and encourage transformative practice.

\section{References}

Alafnan, M. A. (2016) 'Textography: A Multi- Dimensional Applied Genre Analysis of Business Writing in an Educational Institute', Journal of Applied Linguistics and Language Research, 3(6), pp. 264-294.

Archer, A. (2006) 'A Multimodal Approach to Academic "Literacies": Problematising theVisual/ Verbal Divide', Language and Education, 20(6), pp. 449-462.

Basturkmen, H. (2003) 'Specificity and ESP course design', RELC, 34(1), pp. 48-63. 
Bazerman, C. (1998) Editor's introduction. In Other floors, other voices : a textography of a small university buildingpp. xi-x. New Jersey: Lawrence Erlbaum Associates Inc.

Becher, T. and Trowler, P. R. (2001) Academic Tribes And Territories. Buckingham: Open University Press.

Blue, G. (1988. Individualising academic writing tuition. In C. Robinson, Pauline (Ed.), Academic Writing: Process and Product, ELT documents 129. Reading: British Council. Available at:

http://teachingenglish.britishcouncil.org.cn/sites/teacheng/files/ELT-14screen_0.pdf\#page=102 [Accessed: 2 July 2019]

Charles, M. (2012) 'Proper vocabulary and juicy collocations: EAP students evaluate do-ityourself corpus-building', English for Specific Purposes, 31, pp. 93-102.

Coventry University. (2019). (BAWE) British Academic Written English Corpus. Available at: from https://www.coventry.ac.uk/research/research-directories/currentprojects/2015/british-academic-written-english-corpus-bawe/ [Accessed: 01 July 2019].

Coxhead, A. (2000) 'A new academic word list', TESOL Quarterly, 34(2), pp. 213-238.

Coxhead, A. (2011) 'The Academic Word List 10 Years On: Research and Teaching Implications', TESOL Quarterly, 45(2), pp. 355-362.

Ding, A. and Bruce, I. (2017) The English for Academic Purposes Practitioner Operating on the Edge of Academia. Cham: Springer International Publishing.

Dudley-Evans, T. and St John, M. J. (1998) Developments in English for Specific Purposes A multi-disciplinary approach. Cambridge: Cambridge University Press. 
Flowerdew, J., and Costley, T. (2017) Discipline-specific writing : theory into practice. Abingdon: Routledge.

Gourlay, L. (2009) 'Threshold practices: becoming a student through academic literacies', London Review of Education, 7(2), pp. 181-192.

Hale, A., Snow-Gerono, J. and Morales, F. (2008) 'Transformative education for culturally diverse learners through narrative and ethnography', Teaching and Teacher Education, 24, pp. 1413-1425.

Heng, T. (2017) Visual methods in the field Photogpraphy for the social sciences. Abingdon: Routledge.

HESA. (2019) Higher Education Student Statistics: UK, 2017/18 - Subjects studied. Retrieved from https://www.hesa.ac.uk/news/17-01-2019/sb252-higher-educationstudent-statistics/subjects

Hyland, K. (2002a) 'Genre: language, context, and literacy', Annual Review of Applied Linguistics, 22, pp. 113-135.

Hyland, K. (2002b) 'Specificity Revisited: How Far Should we Go Now? English for Specific Purposes', 21, pp. 385-395.

Hyland, K. (2006) 'The ' Other ' English: Thoughts on EAP and Academic Writing', The European English Messenger, 2(15), pp. 34-88.

Hyland, K. (2017) 'English in the disciplines: arguments for specificity', ESP Today, 5(1), pp. 5-23.

Ingle, J. and Yakovchuk, N. (2015) Writing development, co-teaching and academic literacies: exploring the connections. In T. Lillis, K. Harrington, M. R. Lea, and S. Mitchell (Eds.), Working with Academic Literacies. Anderson: Parlor Press. 
Jacobs, C. (2007) 'Towards a critical understanding of the teaching of discipline-specific academic literacies: making the tacit explicit', Journal of Education, 41, pp. 59-81. Jacobs, C. (2015) Opening up the curriculum: moving from the normative in teachers' understanding of disciplinary literacy practices. In T. Lillis, K. Harrington, M. R Lea, \& S. Mitchell (Eds.), Working with Academic Literacies. Anderson: Parlor Press.

Januin, J. and Stephen, J. (2015) 'Exploring discourse competence elements in EAP class presentations through document and ethnographic analyses', Procedia-Social and Behavioral Sciences, 208, pp. 157-166.

Johnson, I. P. (2018)'Driving learning development professionalism forward from within. Journal of Learning Development in Higher Education' Available at: https://journal.aldinhe.ac.uk/index.php/jldhe/issue/view/27 [Accessed: 1 July 2019].

Lea, M. R. and Street, B. V. (2006) 'The Academic Literacies Model: Theory and Applications', Theory into Practice, 45(4), pp. 368-377.

Lillis, T. (2008) 'Ethnography as Method, Methodology, and "Deep Theorizing."' Written Communication, 25(3), pp. 353-388.

Lillis, T. and Curry, M. J. (2006) 'Professional academic writing by multilingual scholars: Interactions with literacy brokers in the production of English-medium texts', Written Communication, 23(1), pp. 3-35.

Lillis, T., Harrington, K., Lea, M. and Mitchell, S. (2015) Working with academic literacies: case studies towards transformative practice. Anderson: Parlor Press.

Lillis, T. and Scott, M. (2007) 'Defining academic literacies research: issues of epistemology, ideology and strategy', Journal of Applied Linguistics, 4(1), pp. 5-32.

Lillis, T, and Tuck, J. (2016) Academic Literacies: a critical lens on writing and reading in the academy. In K. Hyland and P. Shaw (Eds.), The Routledge Handbook of 
English for Academic Purposes (pp. 30-43). Abingdon: Routledge. Lontoc, G. (2014) Transcribing, translating, and (re) constructing identities: The great cultural divide between us and them (Researching Across Languages and Cultures A collection of reflective pieces providing an unusual insight into how doctoral students engage in multilingual and intercultural research No. 1). Available at: https://www.uea.ac.uk/documents/595200/0/CARE+working+paper.pdf\#page=37 [Accessed: 02 July 2019].

Mannion, G. and Ivanič, R. (2007) 'Mapping literacy practices: Theory, methodology, methods', International Journal of Qualitative Studies in Education, 20(1), pp. 1530.

Mccarty, R. and Swales, J. M. (2017) 'Technological change and generic effects in a university Herbarium: A textography revisited', Discourse Studies, 19(5), pp. 561580.

Neumann, R. (2001) Disciplinary Differences and University Teaching. Studies in Higher Education, 26(2), pp. 135-146.

Paltridge, B. (2004) The exegesis as a genre: an ethnographic examination. In L. Ravelli and R. A. Ellis (Eds.), Analysing Academic Writing. London: Continuum.

Paltridge, B. (2006) 'Beyond the text: A textography of Chinese College English writing', University of Sydney Papers in TESOL, 2(2), pp.149-165.

Paltridge, B. (2008) 'Textographies and the researching and teaching of writing', Iberica, 15 , pp. 9-24.

Paltridge, B., Starfield, S., Ravelli, L. J. and Tuckwell, K. (2012) 'Change and stability: Examining the macrostructures of doctoral theses in the visual and performing arts', Journal of English for Academic Purposes, 11(4), pp. 332-344. 
Paltridge, B., Starfield, S., Ravelli, L. and Nicholson, S. (2012) 'Doctoral writing in the visual and performing arts: Two ends of a continuum', Studies in Higher Education, 37(8), pp. 989-1003.

Pérez-Penup, L. (2019) Potentialities of textography to research the construction of authorial identity by professional academic non-native writers of English in the 'soft sciences. In C. Calle Martínez and S. Madarova (Eds.), FOCUS ON LEARNING: CONTRIBUTION TO THE FIELD OF ESP. Universidad Camilo José Cela. Available at:

https://repositorio.ucjc.edu/bitstream/handle/20.500.12020/840/FOCUS ON LEARNING.pdf?sequence=1\#page=39 [Accessed 03 July 2019].

Pink, S. (2012) The visual in ethnography: photography, videos, cultures and individuals. In J. Hughes (Ed.), SAGE visual methods. London: Sage Publication.

Pink, S. (2013) Doing visual ethnography (3rd ed.). London: Sage Publication.

Raimes, A. (1991) Instruction Balance: from theories to practices in the teaching of writing. In Georgetown University Round Table on Languages and Linguistics (GURT) 1991. Washington DC: Georgetown University Press. Available at https://books.google.co.uk/books?hl=en\&lr=\&id=GzgWsZDIVo0C\&oi=fnd\&pg=PA23 $8 \& d q=$ butler+stance + raimes\&ots=pBHPfgN3bk\&sig=GOabKKKw5BpFzHEn2KGnm YBxgNE\#v=onepage\&q=butler\&f=false [Accessed: 02 July 2019].

Ravelli, L., Paltridge, B., Starfield, S. and Tuckwell, K. (2013) 'Extending the notion of 'text': the visual and performing arts doctoral thesis', Visual Communication, 12(4), pp. 395-422.

Russell, D. R., Lea, M., Parker, J., Street, B. and Donahue, T. (2005) Exploring Notions of Genre in Academic Literacies and Writing Across the Curriculum Approaches Across Countries and Contexts. In A. Bonini and D. Figueiredo (Eds.), Genre in a Changing World. West Lafayette: Parlor Press. 
Schwartz, D. (1989) 'Visual Ethnography: Using Photography in Qualitative', Qualitative Sociology, 12(2), pp. 119-154.

Seloni, L. (2014) '"I'm an artist and a scholar who is trying to find a middle point": A textographic analysis of a Colombian art historian's thesis writing', Journal of Second Language Writing, 25, pp. 79-99.

Sizer, J. (2019a) 'Is teaching EAP a profession? A reflection on EAP's professional status, values, community and knowledge', Professional and Academic English, June(52), pp. 1-44. Available at: http://www.uefap.com/esp-sig/journals/ESP SIG Journal Issue-52.pdf [Accessed: 01 July 2019].

Sizer, J. (2019b) Unobtrusive textography of a university building as an innovative research method. Leeds: BALEAP 2019 conference. Available at: https://baleap2019.co.uk/wp-content/uploads/2019/03/BALEAP-Programme.pdf [Accessed: June 012019$].$

Souza, V. V. S. (2012) 'A textography of the complex process of learning and teaching online', Estudos Anglo-Americanos, 37, pp. 10-30. Available at: http://www.nexos.ufsc.br/index.php/reaa/article/view/1614/1137 [Accessed: July 01 2019].

Starfield, S., Paltridge, B. and Ravelli, L. (2014) 'Researching academic writing: what textography affords', International Perspectives on Higher Education Research, 10, pp. 103-120.

Street, B. (2012) New Literacy Studies. In M. Grenfell, D. Bloome, C. Hardy, K. Pahl, J. Rowsell, and B. V. Street (Eds.), Language, Ethnography, and Education: Bridging New Literacy Studies and Bourdieu. Abingdon: Routledge.

Street, B., Lea, M. R. and Lillis, T. (2015) Revisting the question of transformation in academic literacies: the ethnographic imperative. In T. Lillis, K. Harrington, M. R. . Lea, and S. Mitchell (Eds.), Working with Academic Literacies. Anderson: Parlor Press. 
Swales, J. M. (1990) Genre analysis: English in academic and research settings.

Cambridge: Cambridge University Press.

Swales, J. M. (1998) Other floors, other voices: a textography of a small university building. New Jersey: Lawrence Erlbaum Associates Inc.

Swales, J. M. (2000) 'Languages for Specific Purposes', Annual Review of Applied Linguistics , 20, pp. 59-76.

Swales, J. M. (2002) Genre Analysis English in Academic and Research settings. Cambridge: Cambridge University Press.

Swales, J. M. (2003). Is the university a community of practice? In Applied linguistics and communities of practice : selected papers from the annual meeting of the British Association for Applied Linguistics, Cardiff University, September 2002 (p. 220). British Association for Applied Linguistics, in association with Continuum. Available at:

https://books.google.co.uk/books?hl=en\&|r=\&id=cKfZIOlxgnwC\&oi=fnd\&pg=PA203 $\& d q=$ swales+community+of+practice\&ots=9scSUKibl8\&sig=onUvTYcHKBbjlLmGbq $A 7 T m N d i e k \# v=$ onepage $\& q=s w a l e s$ community of practice $\& f=f a l s e$ [Accessed: June $012019]$.

Thompson, D. S. (2019) Understanding how students across the disciplines read images. In Reading Across the Disciplines: Studies in SoTL. Murray: Murray State University.

Trowler, P., Saunders, M. and Bamber, V. (2014) Tribes and territories in the 21st century. Abingdon: Routledge. 
Wahyudi, R. (2014) 'Textbook Evaluation and Ethnography as Method', English for Specific Purposes World, 15(44). Available at:

https://www.academia.edu/10432983/Wahyudi_R._2014_._New_Insights_of_ESP_f rom_Indonesian_Islamic_University_Lessons_from_Textbook_Evaluation_and_Eth nography_as_Method_English_for_Specific_Purposes_World_44_15_1-23 [Accessed: 01 July 2019].

Zhu, H., Ren, W. and Han, Z. (2016) 'The impact of marketization on the communication of Chinese academicians: a genre analytical perspective', Critical Discourse Studies, 13(5), pp. 467-484.

\section{Author details}

Jennifer Sizer is a Senior Lecturer in English for Academic Purposes (EAP) and Presessional Course Leader in the School of Languages and Applied Linguistics at the University of Portsmouth. 